\title{
Controlling Food Poisoning Bacteria in Fermented Chicken Sausage Using Lactobacillus plantarum
}

\author{
Rasha Elsabagh $^{1 *}$, Shaimaa M. Nada ${ }^{2}$, and Elsayed M. Abd-Elaaty ${ }^{2}$ \\ ${ }^{I}$ Department of Food Hygiene and Control, Faculty of Veterinary Medicine, Benha University, 13736 Qaluobia, Egypt \\ ${ }^{2}$ Food Control, Animal Health Research Institute, Agriculture Research Center of Egypt,13829 Shebin El koom Branch, Egypt \\ *Corresponding author's Email: Rasha.alsbagh@fvtm.bu.edu.eg; (D) ORCiD: 0000-0002-1759-7443
}

\begin{abstract}
Lactobacillus plantarum (L. plantarum) bacteria is generally recognized as safe and widely used in the food industry. The current study aimed to study the antimicrobial effects of $L$. plantarum against some food poisoning microorganisms, such as Staphylococcus aureus (S. aureus), Bacillus cereus (B. cereus), and Escherichia coli (E. coli) in oriental fermented chicken sausage for 18 days of storage at $4^{\circ} \mathrm{C}$. The $L$. plantarum has broad-spectrum antimicrobial effects that enhance the quality and safety of food products. L. plantarum reduced the count of $S$. aureus, B. cerus, and E. coli to $1.54,4.26$, and $3.03 \log _{10}$, respectively, after 18 days of refrigerated storage. Moreover, there were significant effects of $L$. plantarum on $\mathrm{pH}$, thiobarbituric acid, total volatile basic nitrogen, and sensory attributes of fermented sausage samples during storage time. It was revealed that $L$. plantarum enhanced the physic-chemical, sensory attributes, and shelf life of fermented chicken sausage. Moreover, L. plantarum inhibited the inoculated food poisoning bacteria in fermented chicken sausage. In conclusion, it is recommended to use $L$. plantarum in fermented meat products as a starter and a bio-preservative to enhance the quality of the fermented chicken sausage.
\end{abstract}

Keywords: Chicken sausage, Food safety, Lactobacillus plantarum, Probiotic

\section{INTRODUCTION}

Food safety is a key concern in the food industry since it has serious and long-term consequences for public health, particularly when people consume food contaminated with harmful bacteria (FDA, 2020). Moreover, meat products with functional ingredients are considered a demand in the meat industry to reduce the risk of food-borne diseases and enhance health conditions (Sirini et al., 2020). In this regard, fermented sausages fortified with probiotic bacteria are considered a functional food with several health-promoting benefits (Lafarga and Hayes, 2017).

Probiotics, such as lactic acid bacteria are generally recognized as safe and are widely used in the food industry (Oleksy and Klewicka, 2018). It has been applied in human medicine for treatment or alternative in the treatment of chronic inflammation, cancer, cardiovascular diseases, and Alzheimer's disease (Woo et al., 2014; Kurhan and Çakir, 2016), as it can enhance individuals' health, physiology, and immunity (Arasu et al., 2016). Moreover, it is used for food fermentation, improving the texture and flavor of sausages, suppressing the spoilage bacteria of food, and prolonging the shelf-life (Lin and Pan, 2017).

Lactobacillus plantarum is one of the Lactic acid bacteria, that has promising characteristics to be applied in the commercial fermented meat industry as well as it has a great antioxidant effect in the fermentation of camel sausages (Ayyash et al., 2019).

Although the effect of L. plantarum inoculation on the quality of fermented meat products was evaluated before (Sun et al., 2016), the current study aimed to focus on the evaluation of not only the antimicrobial effect of L. plantarum against some food poisoning microorganisms, such as Staphylococcus aureus (S. aureus), Bacillus cereus (B. cerus), and Escherchia coli $($ E. coli) but also changes in physicochemical and sensory attributes of inoculated oriental fermented chicken sausage stored at refrigerated temperature for 18 days.

\section{MATERIALS AND METHODS}

\section{Ethical approval}

The present study did not involve either humans or animals as an experimental setup. The experiment was conducted at Animal Health Research Institute, Egypt. 


\section{Bacterial strains}

Referenced pathogenic bacterial strains, including E. coli (Lot No: 020090, Des: NCTC: 12241 and ATCC: 25922), S. aureus (Lot No: 460074, Des: NCTC: 10788 and ATCC: 6538), B. cereus (Lot No: 02900402, Des: NCTC: 10400 and ATCC: 6633), and L. plantarum local strain used in the current study were obtained from Media Unit, Food Hygiene Department, Animal Health Research Institute, Dokki, Giza, Egypt.

Pathogenic strains were adjusted to obtain a count of $6 \log _{10} \mathrm{CFU} \mathrm{mL} \mathrm{m}^{-1}$ and L. plantarum was adjusted at $8 \log _{10}$ $\mathrm{CFU} \mathrm{mL}^{-1}$.

\section{Assessment of in vitro antimicrobial activity of $L$. plantarum against different food poisoning bacteria}

Disc diffusion method was used following Toure et al. (2003) to assess the inhibitory range of $L$. plantarum $\left(10^{6}\right.$, $10^{7}$, and $10^{8} \mathrm{CFU} \mathrm{ml}{ }^{-1}$ ) against E. coli, S. aureus, and B. cereus at $10^{6} \mathrm{CFU} \mathrm{ml}^{-1}$ concentration.

\section{Preparation of chicken sausage}

Minced chicken breast meat was purchased from markets in Elminofia governorate, Egypt. The sausage formulations were prepared according to the formulae detailed by Mejri et al. (2017) with minor modifications using chicken meat instead of camel meat. Briefly, sausage batters were prepared for each experiment based on chicken meat content, mincing it with a meat mincer (MK-G20NR-W, Panasonic, Osaka, Japan). The added ingredients to the minced meats included $25 \mathrm{~g} \mathrm{~kg}^{-1} \mathrm{NaCl}, 10 \mathrm{~g} \mathrm{~kg}^{-1}$ garlic, $4 \mathrm{~g} \mathrm{~kg}^{-1}$ sucrose, and mixed spices $30 \mathrm{~g} \mathrm{~kg}^{-1}$.

Before the experiment, the meat was surface treated with ultraviolet light (UV) (wavelength $385 \mathrm{~nm}$ ) for 15 minutes to minimize background micro-flora according to Morsy et al. (2018).

\section{Challenge study}

The prepared mixture was divided into seven groups, then inoculated with cultured bacteria adjusted at $10^{6}$ for pathogenic bacteria and $10^{8}$ for L. Plantarum. The first group named control entailed UV treated but not inoculated, the second group included E. coli inoculated group, the third group had E. coli + L. plantarum, the fourth group composed of $S$. aureus included group, the fifth group was $S$. aureus $+L$. plantarum, the sixth group contained $B$. cereus infected group, and the seventh group included B. cereus + L. plantarum inoculated group. After inoculation, samples were kept at room temperature $\left(22^{\circ} \mathrm{C}\right)$ for 15 minutes for cell attachment and then stuffed into a sterile polyethylene sausage casing using a handheld sausage filling machine. Samples were kept at $4 \pm 1{ }^{\circ} \mathrm{C}$ for 18 days, and they were analyzed at the beginning of the study as well as days $3,6,9,12,15$, and 18 for remaining microbial populations. The current experiment was repeated three times for each group to obtain mean values for statistical analysis $(n=3)$.

\section{Microbiological assay}

At each sampling day, samples were opened and then $10 \mathrm{~g}$ from each one of them was aseptically transferred into $90 \mathrm{~mL}$ of $0.1 \%$ buffered peptone water (BPW, Biolife) and stomached (model G-560E, Bohemia) for 1 minute. Ten-fold serial dilutions were made in BPW (Biolife) and $1 \mathrm{ml}$ was poured on Eosin methylene blue (EMB, Biolife) for E. coli (ISO 21150, 2006), Baird parker (LO, Biolife) for S. aureus (ISO 6888-1, 2003) and B. Cereus, agar base-MYP (BCMYP, Biolife) with polymyxin B sulphate supplement (Code 4240001) and egg yolk emulsion (Code 42111601) for $B$. cereus (ISO 7932, 2004). Colonies were counted after 24 hours of incubation at $37^{\circ} \mathrm{C}$ and expressed as $\log 10 \mathrm{CFU} \mathrm{gm}^{-1}$.

\section{Physico-chemical evaluation}

The measured parameters were included $\mathrm{pH}$ value using a digital $\mathrm{pH}$-meter (model P107, Consort, Belgium), total volatile base nitrogen (TVB-N, N/100 g of sample), and Thiobarbituric acid reactive substances (TBARS, MDA kg-1) using spectrophotometric (CE 599Universal, USA, AOAC, 2005).

\section{Sensory evaluation}

Sensory evaluation of fermented sausage (control and inoculated groups) was performed under the controlled conditions of temperature $22{ }^{\circ} \mathrm{C}$ and humidity $55 \%$ by seven well-trained panelists who were working in Food Hygiene and Control Department, Animal health research institute, Egypt. The criteria used as the basis of the descriptive organoleptic assessment (color, odor, and texture) with triangle test and the hedonic rating system to score on numerical and continuous scales from 0 (the lowest score for each attribute, very bad) to 9 (the highest score for each attribute, very good). The scale points were used according to ISO 13299 (2003).

\section{Statistical analysis}

Results of physicochemical properties and sensory attributes were tested for normality and homogeneity. Then, a one-way analysis of variance was applied to evaluate the statistical significance of differences between groups followed by an LSD test as post hoc for making multiple comparisons by the Statistical Package for Social science Software 
(Version 25, SPSS Inc.; Chicago, IL, USA). The values were expressed as the mean \pm standard error. A significant difference was used at the $\mathrm{p} \leq 0.05$ probability level. Statistical analysis of concerning results of the effects of $L$. plantarum on food poisoning bacteria was carried out using student's T-test according to Steel and Torrie (1980). Significant differences were calculated at degree of freedom at $\mathrm{p}$ values 0.05 .

\section{RESULTS AND DISCUSSION}

Natural bio-control demand has raised with varying efficacy and impacts on food quality and consumer health (AlJuhaimi et al., 2018). Minimum inhibitory concentration of L. plantarum was evaluated in vitro, results in Table 1 showed that zones of inhibition differed according to the use of L. plantarum concentration. It was found $10^{8} \mathrm{CFU} \mathrm{ml}^{-1}$ concentration had the widest inhibitory zone against $S$. aureus, B. cereus, and E. coli.

\section{Challenge study}

Based on the results in Table 2 L. plantarum showed antimicrobial effect against S. aureus, B. cerus, and E. coli selected for the challenge study, there was a significant difference between groups inoculated with pathogenic bacteria only and those treated with $L$. plantarum $(\mathrm{p} \leq 0.05)$. It was found the pathogenic bacteria of inoculated groups reached a count of 8.61, 7.94, and $8.61 \log _{10}$ for $S$. aureus, B. cereus, and E. coli over the course of the experiment, respectively. $L$. plantarum decreased count of $S$. aureus, B. cereus, and E. coli in treated groups to reach $1.54,4.26$, and $3.03 \log _{10}$ respectively, after day 18 of refrigerated storage. The $L$. plantarum reduced the microbial load of inoculated pathogens mainly against $S$. aureus, followed by E. coli, and B. cereus. The L. plantarum showed antimicrobial properties in fermented chicken sausage (Yadav and Pipaliya, 2017). This might be due to the low $\mathrm{pH}$ level of the product that affects directly inoculated bacteria or the metabolites secreted as organic acids, fatty acids, exopolysaccharides, and bacteriocins (Oleksy and Klewicka, 2018).

Table 1. Antimicrobial activity assessment of Lactobacillus plantarum against Staphylococcus aureus, Bacillus cerus, and Escherichia coli using disc diffusion method

\begin{tabular}{lcccc}
\hline \multirow{2}{*}{ Pathogenic bacteria } & \multicolumn{3}{c}{ Lactobacillus plantarum } \\
\cline { 2 - 4 } & $\mathbf{1 0}^{\mathbf{6}}$ & $\mathbf{1 0}^{\mathbf{7}}$ & $\mathbf{1 0}^{\mathbf{8}}$ \\
\hline Staphylococcus aureus $\left(10^{6}\right)$ & $8 \pm 0.22$ & $12 \pm 0.10$ & $18 \pm 0.15$ & $\mathrm{~mm}$ \\
Bacillus cereus $\left(10^{6}\right)$ & $\mathrm{ND}$ & $9 \pm 0.23$ & $13 \pm 0.11$ & $\mathrm{~mm}$ \\
Escherichia coli $\left(10^{6}\right)$ & $\mathrm{ND}$ & $10 \pm 0.10$ & $15 \pm 0.14$ & $\mathrm{~mm}$ \\
\hline
\end{tabular}

ND*: Not detected

Table 2. Effect of Lactobacillus plantarum on different food poisoning bacteria (log CFU/gm) inoculated in chicken sausage stored at $4^{\circ} \mathrm{C}$

\begin{tabular}{|c|c|c|c|c|c|c|c|}
\hline \multirow{2}{*}{ Groups } & \multicolumn{7}{|c|}{ Storage period (day) } \\
\hline & 1 & 3 & 6 & 9 & 12 & 15 & 18 \\
\hline Staphylococcus aureus $\left(10^{6}\right)$ & $6.38 \pm 0.09$ & $6.89 \pm 0.02$ & $7.12 \pm 0.05$ & $7.56 \pm 0.06$ & $7.88 \pm 0.07$ & $8.20 \pm 0.04$ & $8.61 \pm 0.06$ \\
\hline $\begin{array}{l}\text { Staphylococcus aureus }\left(10^{6}\right)+ \\
\text { Lactobacillus plantarum }\end{array}$ & $6.35 \pm 0.05$ & $5.60 \pm 0.09^{* * *}$ & $5.12 \pm 0.03^{* * * *}$ & $4.81 \pm 0.03^{* * *}$ & $4.00 \pm 0.08^{* * *}$ & $3.73 \pm 0.09^{* * *}$ & $1.54 \pm 0.13^{* * *}$ \\
\hline Bacillus cereus $\left(10^{6}\right)$ & $6.50 \pm 0.08$ & $6.79 \pm 0.02$ & $7.07 \pm 0.03$ & $7.36 \pm 0.04$ & $7.71 \pm 0.04$ & $7.81 \pm 0.02$ & $7.94 \pm 0.03$ \\
\hline $\begin{array}{l}\text { Bacillus cereus }\left(10^{6}\right)+ \\
\text { Lactobacillus plantarum }\end{array}$ & $6.40 \pm 0.05$ & $6.20 \pm 0.00^{* * * *}$ & $5.99 \pm 0.02^{* * *}$ & $5.55 \pm 0.03^{* * *}$ & $5.13 \pm 0.03^{* * *}$ & $4.99 \pm 0.07^{* * *}$ & $4.26 \pm 0.02^{* * *}$ \\
\hline Escherichia coli $\left(10^{6}\right)$ & $6.38 \pm 0.09$ & $6.89 \pm 0.02$ & $7.12 \pm 0.05$ & $7.56 \pm 0.06$ & $7.88 \pm 0.07$ & $8.20 \pm 0.04$ & $8.61 \pm 0.06$ \\
\hline $\begin{array}{l}\text { Escherichia coli }\left(10^{6}\right)+ \\
\text { Lactobacillus plantarum }\end{array}$ & $6.28 \pm 0.15$ & $5.83 \pm 0.08^{* * *}$ & $5.37 \pm 0.04^{* * * *}$ & $4.86 \pm 0.03^{* * *}$ & $4.92 \pm 0.03^{* * *}$ & $3.54 \pm 0.08^{* * * *}$ & $3.03 \pm 0.12^{* * * *}$ \\
\hline
\end{tabular}

Data are presented as (Mean \pm S.E). S. E: Standard error. *** Represents statistical significance at $\mathrm{p} \leq 0.05$

\section{Physico-chemical evaluation}

In this phase of the study, the effect of L. plantarum on freshness, shelf life time, and chemical quality of chicken sausage was evaluated. Results in Table 3 revealed that $\mathrm{pH}$ values in groups that inoculated with L. plantarum were significantly different $(\mathrm{p} \leq 0.05)$ than the control one. Moreover, there was a significant difference $(\mathrm{p} \leq 0.05)$ in the $\mathrm{pH}$ value over the storage period (18 days) in the same group. The L. plantarum decreases $\mathrm{pH}$ values in sausage due to the growth of lactic acid bacteria (Slima et al., 2017). This acidification is a straightforward metric for assessing a starter's effectiveness. Organic acids formation during fermentation reduces $\mathrm{pH}$ and prevents pathogens' growth (Mataragas et al., 2015). Moreover, it has positive effects on the flavor, as it strengthens the perception of aroma (Bonomo et al., 2009).

Concerning TVB-N results during challenge study in Table 4 revealed that TVB-N increased gradually during chilling storage at $4^{\circ} \mathrm{C}$ with significant difference $(\mathrm{p} \leq 0.05)$ between groups inoculated with pathogenic bacteria and 
those treated with $L$. plantarum due to bacterial or enzymatic actions on protein degradation. There was also a significant difference $(\mathrm{p} \leq 0.05)$ in TVB-N values over the storage period (18 days), with prolonged storage time the TVB-N values increased in groups inoculated with pathogenic bacteria, whereas in those treated with L. plantarum decreased. L. plantarum maintains lipid oxidation in fermented sausage (Slima et al., 2017).

Regarding Thiobarbituric acid (TBA), a typical indicator of lipid rancidity in meat products provides useful information on lipid oxidation (Tornuk et al., 2015). Results in Table 5 revealed that TBA increased gradually during extended chilling storage at $4{ }^{\circ} \mathrm{C}$ with significant difference $(\mathrm{p} \leq 0.05)$ between groups inoculated with pathogenic bacteria and those treated with $L$. plantarum due to oxidative action effect on fatty acids. There was a significant difference $(\mathrm{p} \leq 0.05)$ in TBA values over the refrigerated storage period, with prolonged storage time TBA values increased in groups inoculated with pathogenic bacteria, compared to L. plantarum treated groups. The L. plantarum in camel sausages (Ayyash et al., 2019) and chicken sausages (Yadav and Pipaliya, 2017) has a significant antioxidant effect.

Physico-chemical properties, including $\mathrm{pH}, \mathrm{TBA}$, and TVN, in all pathogenic bacteria inoculated groups were evaluated until nine days of storage While, those groups treated with L. plantarum were evaluated till 18 days of refrigerated storage $\left(4^{\circ} \mathrm{C}\right)$ when samples undergo spoilage.

Table 3. Effect of Lactobacillus plantarum on $\mathrm{pH}$ of chicken sausage stored at refrigerator temperature $4^{\circ} \mathrm{C}$

\begin{tabular}{|c|c|c|c|c|c|c|c|}
\hline \multirow{2}{*}{ Groups } & \multicolumn{7}{|c|}{ Storage period (day) } \\
\hline & 1 & 3 & 6 & 9 & 12 & 15 & 18 \\
\hline Control & $5.90 \pm 0.04$ & $6.34 \pm 0.04$ & $6.97 \pm 0.07$ & $\mathrm{~S}$ & $\mathrm{~S}$ & $\mathrm{~S}$ & $\mathrm{~S}$ \\
\hline Staphylococcus aureus $\left(10^{6}\right)$ & $5.86 \pm 0.02$ & $6.51 \pm 0.05^{\mathrm{a}}$ & $7.01 \pm 0.16$ & S & S & $S$ & S \\
\hline $\begin{array}{l}\text { Staphylococcus aureus }\left(10^{6}\right)+ \\
\text { Lactobacillus plantarum }\end{array}$ & $5.74 \pm 0.01^{\mathrm{ab}}$ & $4.87 \pm 0.03^{\mathrm{ab}}$ & $4.50 \pm 0.04^{\mathrm{ab}}$ & $4.47 \pm 0.04$ & $4.23 \pm 0.06$ & $5.00 \pm 0.06$ & $5.35 \pm 0.07$ \\
\hline Bacillus cereus $\left(10^{6}\right)$ & $5.90 \pm 0.03$ & $6.51 \pm 0.05^{\mathrm{a}}$ & $7.01 \pm 0.16$ & S & $\mathrm{S}$ & $\mathrm{S}$ & $\mathrm{S}$ \\
\hline $\begin{array}{l}\text { Bacillus cereus }\left(10^{6}\right)+ \\
\text { Lactobacillus plantarum }\end{array}$ & $5.79 \pm 0.02^{\mathrm{ab}}$ & $4.67 \pm 0.03^{\mathrm{ab}}$ & $4.55 \pm 0.04^{\mathrm{ab}}$ & $4.48 \pm 0.04$ & $4.26 \pm 0.06$ & $5.00 \pm 0.06$ & $5.32 \pm 0.16$ \\
\hline Escherichia coli $\left(10^{6}\right)$ & $5.97 \pm 0.03$ & $6.60 \pm 0.05^{\mathrm{a}}$ & $7.22 \pm 0.08$ & S & S & S & S \\
\hline $\begin{array}{l}\text { Escherichiacoli }\left(10^{6}\right)+ \\
\text { Lactobacillus plantarum }\end{array}$ & $5.84 \pm 0.03^{b}$ & $4.80 \pm 0.03^{\mathrm{ab}}$ & $4.76 \pm 0.03^{\mathrm{ab}}$ & $4.46 \pm 0.04$ & $4.20 \pm 0.05$ & $5.51 \pm 0.07$ & $5.80 \pm 0.08$ \\
\hline
\end{tabular}

Data are presented as (Mean \pm S.E). S.E: Standard error, S: Spoilage depending on sensory evaluation. Significance at $\mathrm{p} \leq 0.05 .{ }^{\mathrm{a}}$ Significant in the control group, ${ }^{\mathrm{b}}$ Significant within corresponding bacterial groups

Table 4. Effect of Lactobacillus plantarum on TVB-N of chicken sausage stored at $4^{\circ} \mathrm{C}$

\begin{tabular}{|c|c|c|c|c|c|c|c|}
\hline \multirow{2}{*}{ Groups } & \multicolumn{7}{|c|}{ Storage period (day) } \\
\hline & 1 & 3 & 6 & 9 & 12 & 15 & 18 \\
\hline Control & $1.65 \pm 0.03$ & $18.33 \pm 0.33$ & $27.72 \pm 0.67$ & $S$ & $\mathrm{~S}$ & $\mathrm{~S}$ & $\mathrm{~S}$ \\
\hline Staphylococcus aureus $\left(10^{6}\right)$ & $1.71 \pm 0.05$ & $19.60 \pm 0.32^{\mathrm{a}}$ & $30.26 \pm 0.65^{\mathrm{a}}$ & $\mathrm{S}$ & $S$ & $\mathrm{~S}$ & $S$ \\
\hline $\begin{array}{l}\text { Staphylococcus aureus }\left(10^{6}\right) \\
+ \text { Lactobacillus plantarum }\end{array}$ & $1.57 \pm 0.03$ & $4.80 \pm 0.20^{\mathrm{ab}}$ & $9.47 \pm 0.25^{\mathrm{ab}}$ & $13.66 \pm 0.26$ & $16.01 \pm 0.51$ & $19.19 \pm 0.34$ & $27.72 \pm 0.67$ \\
\hline Bacillus cereus $\left(10^{6}\right)$ & $1.79 \pm 0.05^{\mathrm{a}}$ & $21.00 \pm 0.55^{\mathrm{a}}$ & $32.06 \pm 0.63^{\mathrm{a}}$ & $\mathrm{S}$ & $\mathrm{S}$ & $\mathrm{S}$ & $\mathrm{S}$ \\
\hline $\begin{array}{l}\text { Bacillus cereus }\left(10^{6}\right)+ \\
\text { Lactobacillus plantarum }\end{array}$ & $1.63 \pm 0.03^{b}$ & $5.54 \pm 0.28^{a b}$ & $10.25 \pm 0.36^{\mathrm{ab}}$ & $14.39 \pm 0.33$ & $17.26 \pm 0.36$ & $19.93 \pm 0.47$ & $29.67 \pm 1.41$ \\
\hline Escherichia. coli $\left(10^{6}\right)$ & $2.09 \pm 0.07^{\mathrm{a}}$ & $21.66 \pm 0.66^{\mathrm{a}}$ & $32.95 \pm 0.53^{\mathrm{a}}$ & $\mathrm{S}$ & $S$ & $S$ & $\mathrm{~S}$ \\
\hline $\begin{array}{l}\text { Escherichiacoli }\left(10^{6}\right)+ \\
\text { Lactobacillus plantarum }\end{array}$ & $1.78 \pm 0.04^{\mathrm{b}}$ & $6.10 \pm 0.10^{\mathrm{ab}}$ & $10.93 \pm 0.33^{\mathrm{ab}}$ & $15.06 \pm 0.59$ & $18.20 \pm 0.39$ & $20.88 \pm 0.61$ & $32.95 \pm 0.53$ \\
\hline
\end{tabular}

Data are presented as (Mean \pm S.E). S.E: Standard error, S: Spoilage depending on sensory evaluation. Significance at $p \leq 0.05$. ${ }^{a}$ Significant in the control group, ${ }^{\mathrm{b}}$ Significant within corresponding bacterial groups

Table 5. Effect of Lactobacillus plantarum on Thiobarbituric acid of chicken sausage stored at refrigerated temperature $4^{\circ} \mathrm{C}$.

\begin{tabular}{|c|c|c|c|c|c|c|c|}
\hline \multirow{2}{*}{ Groups } & \multicolumn{7}{|c|}{ Storage period (day) } \\
\hline & 1 & 3 & 6 & 9 & 12 & 15 & 18 \\
\hline Control & $0.05 \pm 0.00$ & $0.81 \pm 0.03$ & $1.07 \pm 0.06$ & $S$ & $\mathrm{~S}$ & $\mathrm{~S}$ & $\mathrm{~S}$ \\
\hline Staphylococcus aureus $\left(10^{6}\right)$ & $0.05 \pm 0.00$ & $0.90 \pm 0.02$ & $1.23 \pm 0.07$ & $\mathrm{~S}$ & $\mathrm{~S}$ & $\mathrm{~S}$ & $\mathrm{~S}$ \\
\hline $\begin{array}{l}\text { Staphylococcus aureus }\left(10^{6}\right)+ \\
\text { Lactobacillus plantarum }\end{array}$ & $0.04 \pm 0.01$ & $0.14 \pm 0.02^{\mathrm{ab}}$ & $0.32 \pm 0.04^{\mathrm{ab}}$ & $0.49 \pm 0.04$ & $0.66 \pm 0.04$ & $0.81 \pm 0.03$ & $1.07 \pm 0.06$ \\
\hline Bacillus cereus $\left(10^{6}\right)$ & $0.06 \pm 0.01$ & $0.97 \pm 0.04$ & $1.37 \pm 0.06^{\mathrm{a}}$ & $\mathrm{S}$ & S & $\mathrm{S}$ & $\mathrm{S}$ \\
\hline $\begin{array}{l}\text { Bacillus cereus }\left(10^{6}\right)+ \\
\text { Lactobacillus:plantarum }\end{array}$ & $0.05 \pm 0.01$ & $0.19 \pm 0.03^{\mathrm{ab}}$ & $0.40 \pm 0.06^{\mathrm{ab}}$ & $0.57 \pm 0.06$ & $0.74 \pm 0.04$ & $0.88 \pm 0.04$ & $1.37 \pm 0.06$ \\
\hline Escherichia coli $\left(10^{6}\right)$ & $0.06 \pm 0.01$ & $1.05 \pm 0.07^{\mathrm{a}}$ & $1.34 \pm 0.09^{\mathrm{a}}$ & $S$ & $\mathrm{~S}$ & $\mathrm{~S}$ & $\mathrm{~S}$ \\
\hline $\begin{array}{l}\text { Escherichia coli }\left(10^{6}\right)+ \\
\text { Lactobacillus plantarum }\end{array}$ & $0.05 \pm 0.00$ & $0.35 \pm 0.14^{\mathrm{ab}}$ & $0.53 \pm 0.05^{\mathrm{ab}}$ & $0.64 \pm 0.07$ & $0.79 \pm 0.05$ & $1.00 \pm 0.07$ & $1.49 \pm 0.07$ \\
\hline
\end{tabular}

Data are presented as (Mean \pm S.E). S.E: Standard error, S: Spoilage depending on sensory evaluation. Significance at $\mathrm{p} \leq 0.05 .{ }^{\text {a }}$ Significant in the control group, ${ }^{\mathrm{b}}$ Significant within corresponding bacterial groups 


\section{Sensory evaluation}

Sensory evaluation performed to assess the overall acceptability (odor, texture, and color) of chicken sausage during storage at $4^{\circ} \mathrm{C}$ is shown in Table 6 . Results showed that there was a significant difference $(\mathrm{p} \leq 0.05)$ between samples inoculated with pathogenic bacteria only and treated groups with L. plantarum on overall acceptability (odor, texture, and color). Inoculated pathogenic bacteria groups in the current study spoiled at day nine.

Over the refrigerated storage period, there was a significant difference $(p \leq 0.05)$ in overall acceptability values between the first group (control one) and groups inoculated with pathogenic bacteria and that inoculated with pathogenic bacteria and L. Plantarum. During storage, fermented chicken sausage became unaccepted or rejected in groups without L. plantarum at day 9 of storage and still acceptable in those treated with $L$. plantarum until day 18 . Generally, all organoleptic data were in agreement with microbiological, physical, and chemical quality indices present in Tables 1, 2, 3 , and 4. Changes in color, odor, and texture during refrigerated storage occurred due to lipid oxidation and protein degradation (Sirocchi et al., 2017). Changes can also be attributed to the ability of lactic acid bacteria to produce small organic substances prevent oxidation mechanism, so enhance the aroma and give specific organoleptic attributes of the products (Tagg et al., 1976). Consumers' demand for foods depends mainly on sensory attributes (Fernández-López et al., 2005). The current study results were in agreement with Slima et al. (2017) who used L. plantarum to evaluate the enhanced quality and safety of beef sausages stored at $4^{\circ} \mathrm{C}$ for 10 days.

Table 6. Effect of Lactobacillus plantarum on sensory attributes of chicken sausage stored at $4^{\circ} \mathrm{C}$

\begin{tabular}{|c|c|c|c|c|c|c|c|}
\hline \multirow{2}{*}{ Groups } & \multicolumn{7}{|c|}{ Storage period (day) } \\
\hline & 1 & 3 & 6 & 9 & 12 & 15 & 18 \\
\hline Control & $9.11 \pm 0.14$ & $6.44 \pm 0.13$ & $3.80 \pm 0.21$ & $\mathrm{R}$ & $\mathrm{R}$ & $\mathrm{R}$ & $\mathrm{R}$ \\
\hline Staphylococcus aureus $\left(10^{6}\right)$ & $8.44 \pm 0.21^{\mathrm{a}}$ & $6.44 \pm 0.13$ & $3.80 \pm 0.21$ & $\mathrm{R}$ & $\mathrm{R}$ & $\mathrm{R}$ & $\mathrm{R}$ \\
\hline $\begin{array}{l}\text { Staphylococcus aureus }\left(10^{6}\right) \\
+ \text { Lactobacillus plantarum }\end{array}$ & $9.22 \pm 0.18^{b}$ & $8.70 \pm 0.10^{a b}$ & $7.23 \pm 0.07^{\mathrm{ab}}$ & $6.91 \pm 0.02^{a b}$ & $6.14 \pm 0.08^{a b}$ & $5.30 \pm 0.14^{\mathrm{ab}}$ & $4.93 \pm 0.18^{a b}$ \\
\hline Bacillus cereus $\left(10^{6}\right)$ & $9.01 \pm 0.09$ & $6.44 \pm 0.13$ & $3.47 \pm 0.13$ & $\mathrm{R}$ & $\mathrm{R}$ & $\mathrm{R}$ & $\mathrm{R}$ \\
\hline $\begin{array}{l}\text { Bacillus cereus }\left(10^{6}\right)+ \\
\text { Lactobacillus plantarum }\end{array}$ & $9.06 \pm 0.06$ & $8.81 \pm 0.04^{\mathrm{ab}}$ & $7.74 \pm 0.10^{\mathrm{ab}}$ & $7.31 \pm 0.12^{\mathrm{ab}}$ & $6.84 \pm 0.06^{\mathrm{ab}}$ & $6.06 \pm 0.05^{\mathrm{ab}}$ & $5.07 \pm 0.09^{\mathrm{ab}}$ \\
\hline Escherichia coli $\left(10^{6}\right)$ & $9.47 \pm 0.20$ & $6.10 \pm 0.46$ & $2.80 \pm 0.39^{\mathrm{a}}$ & $\mathrm{R}$ & $\mathrm{R}$ & $\mathrm{R}$ & $\mathrm{R}$ \\
\hline $\begin{array}{l}\text { Escherichia coli }\left(10^{6}\right)+ \\
\text { Lactobacillus plantarum }\end{array}$ & $9.22 \pm 0.18$ & $8.70 \pm 0.10^{\mathrm{ab}}$ & $7.73 \pm 0.13^{a b}$ & $6.91 \pm 0.02^{\mathrm{ab}}$ & $6.14 \pm 0.08^{a b}$ & $5.30 \pm 0.14^{\mathrm{ab}}$ & $4.62 \pm 0.14^{\mathrm{ab}}$ \\
\hline
\end{tabular}

Data are presented as (Mean \pm S.E). S.E: Standard error, R: Rejected depending on sensory evaluation. Significance at $\mathrm{p} \leq 0.05$. ${ }^{\mathrm{a}}$ Significant in the control group, ${ }^{\mathrm{b}}$ Significant within corresponding bacterial groups

\section{CONCLUSION}

Results of the present study revealed that $L$. plantarum has broad in vitro and in vivo antimicrobial effects against $S$. aureus, B. cereus, and E. coli. The use of L. plantarum in chicken sausage enhances shelf lifetime, physicochemical properties, sensory attributes, and safety until day 18 , whereas infected groups inadmissible at day 9 of storage $4^{\circ} \mathrm{C}$. It is recommended to use $L$. plantarum in fermented meat products as a starter and a bio-preservative to enhance the quality.

\section{DECLARATION}

\section{Authors' contributions}

Rasha Elsabagh designed the plan of study, revised the research article. Shaimaa M. Nada and Elsayed M. AbdElaaty analyzed the data, performed laboratory experiments, and drafted the manuscript. Rasha Elsabagh provided the experimental tools. All authors checked the statistical results and approved the final version of the article.

\section{Competing interests}

The authors declare no conflicts of interest.

\section{Ethical considerations}

Ethical issues (including plagiarism, consent to publish, misconduct, data fabrication and/or falsification, double publication and/or submission, and redundancy) have been checked by the authors.

\section{Acknowledgments}

The authors express their sincere gratitude to DR $\backslash$ Abd El-Aziz M.A, Food Control, Animal Health Research Institute, Agriculture research center, for all the support provided. 
Al-Juhaimi FY, Ghafoor K, Özcan MM, Jahurul MHA, Babiker EE, Jinap S, Sahena F, Sharifudin MS, and Zaidul ISM (2018). Effect of various food processing and handling methods on preservation of natural antioxidants in fruits and vegetables. Journal of Food Science and Technology, 55: 3872-3880. DOI: https://www.doi.org/10.1007/s13197-018-3370-0

Arasu M, Al-Dhabi N, Ilavenil S, Choi K, and Srigopalram S (2016). In vitro importance of probiotic L. plantarum related to medical field. Saudi Journal of Biological Sciences, 23: 6-10. DOI: https://www.doi.org/10.1016/j.sjbs.2015.09.022

Association of Official Agricultural Chemists (AOAC) (2005). Official methods of analysis (18 ${ }^{\text {th }}$ edn). Association of Official Analytical, Chemists, Washington Available https://www.scirp.org/(S(351jmbntvnsjt1aadkposzje))/reference/ReferencesPapers.aspx?ReferenceID=2033299

Ayyash M, Shao-Quan L, Aysha A, Mouza A, Bakhita R, Anas A, Tareq O, and Amin O (2019). In vitro investigation of healthpromoting benefits of fermented camel sausage by novel probiotic Lactobacillus. plantarum: A comparative study with beef sausages. LWT-Food Science and Technology, 99: 346-354. DOI: https://www.doi.org/10.1016/j.1wt.2018.09.084

Bonomo MG, Ricciardi A, Zotta T, Sico MA, and Salzano G (2009). Technological and safety characterization of coagulase-negative staphylococci from traditionally fermented sausages of Basilicata Region (Southern Italy). Meat Science, 83: 15-23. DOI: https://www.doi.org/10.1016/j.meatsci.2009.03.006

Fernández-López J, Zhi N, Aleson-Carbonell L, Pérez-Alvarez JA, and Kuri V (2005). Antioxidant and antibacterial activities of natural extracts: Application in beef meatballs. Meat Science, 69(3): 371-380. DOI: https://www.doi.org/10.1016/j.meatsci.2004.08.004

Food and Drug Administration (FDA) (2020). Outbreaks of foodborne illness. Available at: https://www.fda.gov/food/recallsoutbreaks-emergencies/outbreaks-foodborne-illness

International Organization for Standardization (ISO) 13299 (2003). Sensory analysis - Methodology - General guidance for establishing a sensory profile. Available at: https://www.iso.org/standard/37227.html

International Organization for Standardization (ISO) 21150 (2006). Cosmetics. Microbiology - Detection of Escherichia coli. Available at: https://www.iso.org/obp/ui/es/\#iso:std:iso:21150:ed-1:en

International Organization for Standardization (ISO) 6888-1 (2003). Horizontal methods for the enumeration of coagulase-positive Staphylococci (Staphylococcus aureus and other species), Technique using Baird-Parker medium. Available at: http://www.oxoid.com/pdf/iso-food-safety-brochure.pdf

International Organization for Standardization (ISO) 7932 (2004). Horizontal method for the enumeration of presumptive Bacillus cereus-colony-count technique at $30^{\circ} \mathrm{C}$. Available at: http://www.oxoid.com/pdf/iso-food-safetybrochure.pdf

Kurhan Ş, and Çakir I (2016). NA-bioprotective effects of lactic acid bacteria against aflatoxin B1. Current Research in Nutrition and Food Science, 4(2): 87-91. DOI: https://www.doi.org/10.1016/j.meatsci.2004.08.004

Lafarga T, and Hayes M (2017). Bioactive protein hydrolysates in the functional food ingredient industry: Overcoming current challenges. Food Reviews International, 33(3): 217-246. DOI: https://www.doi.org/10.1080/87559129.2016.1175013

Lin TH, and Pan TM (2017). Characterization of an antimicrobial substance produced by L. plantarum NTU 102 . Journal of Microbiology, Immunology and Infection, 52(3): 409-417. DOI: https://www.doi.org/10.1016/j.jmii.2017.08.003

Mataragas M, Bellio A, Rovetto F, Astegiano S, Decastelli L, and Cocolin L (2015). Risk-based control of food-borne pathogens $L$. monocytogenes and Salmonella enterica in the Italian fermented sausages Cacciatore and Felino. Meat Science, 103: 39-45. DOI: https://www.doi.org/10.1016/j.meatsci.2015.01.002

Mejri L, Ziadi A, El Adab S, Boulares M, Essid I, and Hassouna M (2017). Effect of commercial starter cultures on physicochemical, microbiological and textural characteristics of a traditional dry fermented sausage reformulated with camel meat and hump fat. Journal of Food Measurement and Characterization, 11(2): 758-767. https://www.doi.org/10.1007/s11694-016-9445-6

Morsy MK, Elsabagh R, and Trinetta V (2018). Evaluation of novel synergistic antimicrobial activity of nisin, lysozyme, EDTA nanoparticles, and/or Zn Oxide nanoparticles to control foodborne pathogens on minced beef. Food Control, 92: 249-254. DOI: https://www.doi.org/10.1016/j.foodcont.2018.04.061

Oleksy M, and Klewicka E (2018). Exopolysaccharides produced by Lactobacillus sp.: Biosynthesis and applications. Crit. Rev. Food Science and Nutrition, 58: 450-462. DOI: https://www.doi.org/10.1080/10408398.2016.1187112

Sirini N, Frizzo LS, Aleu G, Soto LP, and Rosmini MR (2020). Use of probiotic microorganisms in the formulation of healthy meat products. Current Opinion in Food Science, 38: 141-146. DOI: https://www.doi.org/10.1016/j.cofs.2020.11.007

Sirocchi V, Devlieghere F, Peelman N, Sagratini G, Maggi F, Vittori S, and Ragaert P (2017). Effect of rosmarinus officinalis L. essential oil combined with different packaging conditions to extend the shelf life of refrigerated beef meat. Food Chemistry, 221: 1069-1076. DOI: https://www.doi.org/10.1016/j.foodchem.2016.11.054

Slima SB, Naourez K, Imen T, Mehdi T, Feki-Tounsi M, Hafedh M, Iskandar M, Ana H, Francisco J, Claudia P et al. (2017). Effect of partial replacement of nitrite with a novel probiotic Lactobacillus plantarum TN8 on color, physico-chemical, texture and microbiological properties of beef sausages. LWT-Food Science and Technology, 86: 219-226. DOI: https://www.doi.org/10.1016/j.lwt.2017.07.058

Steel R, and Torrie J (1980). Principles and procedures of statistics: A biometrical approach. New York: McGraw and Hill, p. 593. Available

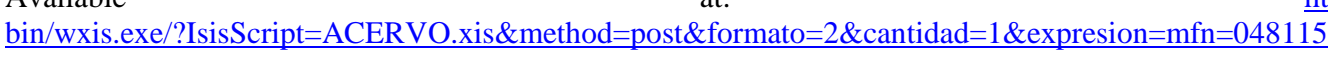

Sun Q, Chen Q, Li F, Zheng D, and Kong B (2016). Biogenic amine inhibition and quality protection of Harbin dry sausages by inoculation with Staphylococcus xylosus and Lactobacillus plantarum. Food Control, 68: 358-66. DOI: https://www.doi.org/10.1016/j.foodcont.2016.04.021

Tagg JR, Dajani AS, and Wannamaker LW (1976). Bacteriocins of gram-positive bacteria. 756. DOI: https://www.doi.org/10.1128/mr.59.2.171-200.1995 
Tornuk F, Hancer M, Sagdic O, and Yetim H (2015). LLDPE based food packaging incorporated with nanoclays grafted with bioactive compounds to extend shelf life of some meat products. LWT-Food Science and Technology, 64(2): 540-546. DOI: https://www.doi.org/10.1016/j.lwt.2015.06.030

Toure R, Kheadr E, Lacroix C, Moroni O, and Fliss I (2003). Production of anti-bacterial substances by bifidobacterial isolates from infant stool active against Listeria monocytogen. Journal of Applied Microbiology, 95(5): 1058-1069. DOI: https://www.doi.org/10.1046/j.1365-2672.2003.02085.X

Woo JY, Gu W, Kim KA, Jang SE, Han MJ, and Kim DH (2014). Lactobacillus.pentosus var Lactobacillus. plantarum C29 ameliorates memory impairment and inflammaging in a D-galactose-induced accelerated aging mouse model. Anaerobe, 27: 2226. DOI: https://www.doi.org/10.1016/j.anaerobe.2014.03.003

Yadav AS, and Pipaliya G (2017). Antioxidant and antimicrobial profile of chicken sausages prepared after fermentation of minced chicken meat with Lactobacillus. plantarum and with additional dextrose and starch. LWT-Food Science and Technology, 77: 249-258. DOI: https://www.doi.org/10.1016/j.lwt.2016.11.050 